\title{
ANALISIS KEPUASAN MAHASISWA TERHADAP KUALITAS SISTEM FINGERPRINT SCANNER MASJID DENGAN METODE STRUCTURAL EQUATION MODELING (SEM)
}

\author{
TRIANA HARMINI ${ }^{1}$, FAISAL REZA PRADANA ${ }^{2}$, NAUFAL FIKRI AL HAZMI ${ }^{3}$ \\ ${ }^{1}$ Program Studi Teknik Informatika Universitas Darussalam Gontor \\ triana@unida.gontor.ac.id \\ ${ }^{2}$ Program Studi Teknik Informatika Universitas Darussalam Gontor \\ faisal@unida.gontor.ac.id \\ ${ }^{3}$ Program Studi Teknik Informatika Universitas Darussalam Gontor \\ naufal.fikri@unida.gontor.ac.id
}

First Received: 24-03-2020; Accepted: 28-04-2020

\begin{abstract}
Abstrak
Penggunaan teknologi fingerprint scanner telah berkembang pesat dan luas, terutama dalam bidang keamanan. Pada instansi perkantoran maupun pendidikan fingerprint digunakan sebagai alat absensi karena tidak dapat dipalsukan. Universitas Darussalam Gontor sebagai lembaga pendidikan juga menggunakan fingerprint sebagai alat absensi mahasiswa ke masjid. Absensi mahasiswa ke masjid dijadikan sebagai salah satu penilaian non-akademik mahasiswa. Absensi menggunakan fingerprints canner baru pertama kali digunakan pada tahun ajaran 2018/2019 sehingga memerlukan evaluasi untuk mengetahui keberhasilan sistem dan kepuasan pengguna. Penelitian ini bertujuan untuk menentukan faktor yang mempengaruhi kepuasan mahasiswa terhadap fingerprint scanner dan menentukan indeks kepuasan mahasiswa terhadap fingerprint scanner. Penelitian ini menggunakan metode Structural Equation Modeling (SEM) untuk menganalisis hubungan antara kualitas sistem fingerprint scanner dengan kepuasan mahasiswa. Kualitas sistem pada fingerprint scanner diukur berdasarkan teori DeLone \& McLean yang terdiri dari enam variabel yaitu kualitas sistem, kualitas informasi, kualitas layanan, penggunaan, kepuasan pengguna dan manfaat bersih. Metode pengumpulan data yang digunakan adalah metode random sampling. Data dikumpulkan dengan menyebarkan kuesioner secara acak kepada 120 mahasiswa UNIDA Gontor. Untuk menganalisis data menggunakan bantuan software AMOS. Hasil analisis data menunjukkan bahwa model DeLone \& McLean dapat digunakan untuk mengukur kepuasan mahasiswa terhadap sistem fingerprint scanner masjid karena model teridentifikasi dan memenuhi kriteria Goodness of Fit. Hasil penelitian menjelaskan bahwa indeks kepuasan mahasiswa UNIDA
\end{abstract}

Kata kunci: Fingerprint scanner; Kepuasaan mahasiswa; Structural Equation Modelling (SEM)

\section{ANALYSIS OF STUDENT SATISFACTION ON QUALITY OF MASTER FINGERPRINT SCANNER SYSTEM WITH STRUCTURAL EQUATION MODELING (SEM) METHOD}

\begin{abstract}
The use of fingerprint scanner technology has developed rapidly and wideky, especially in security. Fingerprint is used at office as well as in education as an attendance tool because it cannot be falsified. Universitas Darussalam Gontor as an
\end{abstract}


educational institution also uses it as a means of student attendance to the mosque. The attendance to the mosque is used as a non-academic assessment. Time attendance in fingerprint scanner has been employed since academic year $2018 / 2019$, so it requires an evaluation to find out the success of the system and user satisfaction. This study aims at determining the factors that influence student satisfaction and examines the index of student satisfaction with fingerprint scanners. This study implemented the Structural Equation Modeling (SEM) method to analyze the relationship between the quality of the fingerprint scanner system and student satisfaction. The quality of the system in the fingerprint scanner was measured based on DeLone \& McLean's theory which consisted of six variables namely system quality, information quality, service quality, usage, user satisfaction and net benefits. The data collection method used was the random sampling method. Data were collected by distributing questionnaires randomly to 116 UNIDA Gontor students. Technique of data analysis used was AMOS software. The results of data analysis showed that the DeLone \& McLean model could be applied to measure student satisfaction with the mosque's fingerprint scanner system. The model was identified and it met the Goodness of Fit criteria. The results of the study explained that the UNIDA Gontor student satisfaction index against the mosque's fingerprint scanner system was at $76.5 \%$ and it represented high procentage.

Keywords: Fingerprint scanner; User satisfaction; Structural Equation Modelling (SEM)

\section{PENDAHULUAN}

Teknologi merupakan sarana yang dapat membantu meningkatkan kenyamanan hidup manusia. Teknologi telah berkembang dengan pesat pada berbagai aspek atau bidang. Pada bidang pendidikan telah dikembangkan sistem informasi untuk membantu guru melakukan pembelajaran jarak jauh dengan menggunakan e-learning. Pada bidang transportasi telah berkembang ojek online serta pada bidang keuangan telah berkembang Electronic Data Capture (EDC). Salah satu teknologi yang sedang berkembang saat ini adalah teknologi fingerprint scanner. Penggunaan teknologi fingerprint scanner telah berkembang pesat dan luas, terutama dalam bidang keamanan. Pada instansi perkantoran maupun pendidikan fingerprint digunakan sebagai alat absensi karena tidak dapat dipalsukan. Dengan menggunakan sistem fingerprint scanner, hasil absensi jauh lebih praktis dan akurat karena sidik jari setiap orang berbeda-beda (Ngantung et al., 2014). Selain itu, absensi dengan menggunakan sistem fingerprint scanner dapat mempermudah perekapan dan pemantauan kehadiran pegawai.

Universitas Darussalam Gontor merupakan universitas berbasis pesantren dimana penilaian prestasi mahasiswa tidak hanya penilaian akademik melainkan penilaian nonakademik. Penilaian non-akademik mahasiswa dilakukan melalui Angka Kredit Penunjang Akademik Mahasiswa (AKPAM). Penilaian AKPAM meliputi berbagai kegiatan mahasiswa 
baik akademis maupun non-akademis, misalnya delegasi lomba, mengikuti kajian, seminar, workshop, kepanitian suatu acara termasuk juga keaktifan mahasiswa sholat berjamaah di masjid. Absensi mahasiswa ke masjid sebelumnya dilakukan secara manual dengan absen setelah sholat berjamaan oleh musyri (pengasuh) asrama di bawah naungan Direktorat Kepengasuhan. Dengan adanya absen manual ini sering terjadi kesalahan absen dan rekap yang dapat merugikan mahasiswa. Mahasiswa juga terkadang malas untuk menunggu absen manual ini.

Untuk meningkatkan disiplin mahasiswa sholat berjamaah ke masjid, Universitas Darussalam Gontor sebagai lembaga pendidikan menggunakan fingerprint sebagai alat absensi mahasiswa ke masjid. Dengan adanya fingerprint scanner ini diharapkan dapat mempermudah pengabsenan dan perekapan keaktifan mahasiswa ke masjid. Sistem pengabsenan dengan menggunakan fingerprint dapat dijadikan sebagai alat pengawasan dan pengendalian yang cepat, tepat, dan akurat karena secara langsung merekam sidik jari setiap penggunanya.

Presensi sidik jari (fingerprint) adalah alat yang digunakan untuk merekam kehadiran seseorang dalam suatu kelembagaan dimana hasil rekapitulasi presensi fingerprint merupakan bukti autentik yang tidak dapat diragukan lagi kebenarannya (Kristin et al., 2016). Fingerprint menggunakan sistem keamanan biometrika berupa sidik jari dengan sistem komputerisasi. Teknologi yang digunakan dalam sistem fingerprint scanner meliputi registrasi sidik jari, download data dan sidik jari, upload data pengguna, pengaturan jam kerja, download data presensi, dan kalkulasi laporan (Ismawati \& Mazia, 2016). Dengan pengabsenan menggunakan sistem fingerprint dapat dilakukan dengan cepat dan akurat.

Sistem fingerprint scanner diterapkan di Universitas Darussalam Gontor pada awal tahun ajaran 2018/2019 sehingga terdapat beberapa kekurangan baik secara teknik maupun non-teknis pada sistem komputerisasi dan alat scanner. Kendala-kendala teknik yang sering terjadi pada absensi fingerprint di masjid adalah sensor yang tidak sensitif ketika mahasiswa absen. Kendala non-teknik yang terjadi adalah terdapat beberapa mahasiswa yang belum terdaftar pada sistem sehingga tidak dapat melakukan absen. Untuk itu perlu dilakukan analisis kualitas sistem fingerprint scanner yang ada di Universitas Darusssalam Gontor.

Pengukuran kualitas suatu sistem teknologi sangat diperlukan bagi manajemen untuk mengidentifikasi faktor-faktor yang menyebabkan suatu sistem dapat berjalan sesuai dengan harapan. Kualitas sistem merupakan karakteristik dari informasi yang melekat mengenai sistem itu sendiri yang mana kualitas sistem merujuk pada seberapa baik kemampuan 
perangkat keras, perangkat lunak, dan kebijakan prosedur dari sistem informasi yang dapat menyediakan informasi kebutuhan pemakai (Septianita et al., 2014). Tujuan diterapkan sistem baru fingerprint scanner masjid pada pengabsenan sholat berjamaah mahasiswa ini diharapkan semakin memudahkan mahasiswa dalam melakukan absensi kehadiran sholat berjamaah di masjid dan memudahkan Direktorat Kepengasuhan terutama tim AKPAM (Angka Kredit Penunjang Akademik Mahasiswa) melakukan perekapan.

Salah satu penelitian yang terkenal mengenai kualitas sistem teknologi informasi adalah teori DeLone dan Mclean dengan merefleksi ketergantungan dari enam faktor kualitas sistem yaitu Kualitas Sistem (system quality), kualitas informasi (information quality), kualitas layanan, kepuasan pengguna (user satisfaction), pengguna (user), dan manfaat bersih (DeLone \& McLean, 2016). Model DeLone \& McLean menjadi dasar untuk memahami skala ukuran dari keberhasilan suatu model sistem informasi (DeLone \& McLean, 2003). Dari penelitian Winda, Wahyu, dan Alfi (2014) memberikan bukti bahwa kualitas informasi, kualitas sistem dan kualitas pelayanan berpengaruh secara signifikan terhadap variabel penggunaan dan variabel kepuasan pengguna. Variabel penggunaan berpengaruh secara signifikan terhadap variabel kepuasan pengguna dan manfaat bersih. Variabel kepuasan pengguna memiliki pengaruh secara signifikan terhadap manfaat bersih (Septianita et al., 2014).

Kepuasan penggunan merupakan salah satu faktor yang dapat mempengaruhi kualitas suatu sistem teknologi. Pengguna dari sistem fingerprint scanner di Unversitas Darussalam Gontor adalah mahasiswa Universitas Darussalam Gontor. Kepuasan merupakan perasaan senang atau kecewa seseorang setelah membandingkan antara kinerja suatu produk dengan harapan awal sebelum menggunakan produk tersebut (Indriani \& Adryan, 2009). Kepuasan pengguna sistem adalah respon dan umpan balik yang dirasakan pengguna setelah menggunakan sistem informasi (Saputro et al., 2016). Dalam penelitian ini kepuasan mahasiswa terhadap kualitas sistem fingerprint scanner dapat diartikan sebagai perasaan puas dan senang mahasiswa setelah harapan awalnya tercukupi terhadap sistem fingerprint scanner.

Pengukuran kepuasan mahasiswa terhadap kualitas sistem fingerprint scanner dapat dilakukan dengan menggunakan pendekatan model Structural Equation Modelling (SEM). SEM atau disebut juga dengan model persamaan struktural adalah serangkaian teknik-teknik statistika yang memungkinkan pengujian serangkaian hubungan yang cukup rumit dan simultan (Ferdinand, 2006). SEM merupakan teknik analisis multivariat yang dikembangkan 
untuk menutupi kelemahan dan keterbatasan metode analisis sebelumnya dalam penelitian statistika yaitu analisis regresi, path analisis, dan analisis faktor konfirmatori. SEM merupakan metode analisis data yang dilakukan untuk menjelaskan hubungan antar variabel yang ada dalam penelitian. Di dalam teori SEM terdapat dua variabel yakni variabel laten dan variabel manifes. Variabel laten adalah variabel yang tidak dapat diukur nilainya langsung kecuali adanya variabel manifes. Sedangkan variabel manifes adalah variabel yang dapat diukur langsung. Variabel laten terbagi menjadi dua yakni variabel laten endogen dan variabel laten eksogen. Variabel laten endogen merupakan variabel yang tidak bebas sedangkan variabel laten eksogen merupakan variabel yang bebas. Tahapan analisis SEM dapat dilakukan dengan cara berikut: pengembangan model teoritis, pengembangan diagram alur (Path Diagram), konversi diagram alur ke dalam persamaan SEM, pemilihan matriks input dan teknik estimasi, menilai problem identifikasi, evaluasi model, dan interpretasi dan modifikasi model (Sasongko et al., 2016).

Penelitian ini bertujuan untuk menentukan faktor yang mempengaruhi kepuasan mahasiswa terhadap fingerprint scanner dan menentukan indeks kepuasan mahasiswa terhadap fingerprint scanner. Faktor-faktor kualitas sistem fingerprint scanner yang digunakan dalam penelitian ini menggunakan teori De Lone dan Mclean. Analisis data yang digunakan untuk mengukur indek kepuasaan mahasiswa terhadap sistem fingerprint scanner menggunakan pendekatan model Structural Equation Modelling (SEM).

\section{METODE PENELITIAN}

Penelitian ini merupakan penelitian kuantitatif dengan menggunakan metode survey. Variabel yang digunakan dalam penelitian ini meliputi variabel endogen dan variabel eksogen. Pada penelitian ini kualitas sistem (KS), kualitas informasi (KI), kualitas layanan $(\mathrm{KL})$, penggunaan $(\mathrm{P})$ dan manfaat bersih $(\mathrm{MB})$ merupakan variabel eksogen sedangkan kepuasan mahasiswa (KM) merupakan variabel endogen. Populasi dari penelitian ini adalah seluruh mahasiswa Universitas Darussalam Gontor Ponorogo di tahun ajaran 2018/2019 yang berjumlah 1201 mahasiswa yang bertempat tinggal di asrama kampus. Teknik pengambilan sampel dalam penelitian ini menggunakan random sampling. Jumlah sampel yang tepat untuk menggunakan analisis SEM sebanyak 100 - 200 responden (Ferdinand, 2006). Ukuran sampel penelitian diambil sebanyak 120 orang. 


\section{Instrumen Penelitian}

Instrumen penelitian yang digunakan dalam penelitian ini berupa angket kuisioner. Angket yang digunakan dalam penelitian ini berupa pertanyaan tertutup dengan lima pilihan jawaban yaitu Sangat Setuju (5), Setuju (4), Ragu-ragu (3), Tidak Setuju (2), dan Sangat Tidak Setuju (1). Sebelum digunakan dalam penelitian, angket diujicobakan dengan skala kecil untuk mengetahui validitas dan reliabilitas angket. Validitas angket dilakukan oleh pakar bahasa agar responden mudah dalam memahami pertanyaan/pernyataan yang terdapat pada angket. Reliabilitas adalah tingkat ketetapan suatu instrumen untuk mengukur apa yang harus diukur. Nilai ideal koefisien reliabilitas adalah di atas $0,7(>0,7)$. Untuk mencari reliabilitas digunakan rumus Cronbach Alpha yaitu :

$$
r_{11}=\left(\frac{k}{k-1}\right) x\left(1-\frac{\sum S_{i}^{2}}{S_{t}^{2}}\right)
$$

Dengan :

$\mathrm{r}_{11}=$ koefisien reliabilitas sampel secara keseluruhan

$\mathrm{k} \quad=$ jumlah butir pertanyaan

$\sum S_{i}^{2}=$ jumlah varians butir

$S_{t}^{2} \quad=$ jumlah varians total

\section{Pengumpulan Data}

Pada penelitian ini pengumpulan data dilakukan dengan menggunakan angket kuisioner dengan cara penyebaran angket kuisioner kepada sampel yang telah ditetapkan sebanyak 120 orang. Penyebaran kuisioner dilakukan untuk mendapatkan data kepuasaan mahasiswa terhadap kualitas sistem fingerprint scanner dan menentukan indeks kepuasan mahasiswa terhadap fingerprint scanner.

\section{Teknik Analisis Data}

Teknik analisis data yang digunakan dalam penelitian ini menggunakan analisis Structural Equation Modeling (SEM) menggunakan program LISREL 8.3. Analisis SEM digunakan untuk mengetahui faktor-faktor yang mempengaruhi kualitas sistem fingerprint scanner. Tahapan analisis SEM yang digunakan dalam penelitian ini meliputi: pengembangan model teoritis, pengembangan diagram alur (Path Diagram), konversi diagram alur ke dalam persamaan SEM, pemilihan matriks input dan teknik estimasi, menilai problem identifikasi, evaluasi model, dan interpretasi dan modifikasi model. Dengan landasan teori yang ada pada analisis SEM menunjukkan bahwa kualitas sistem, kualitas informasi, kualitas layanan, penggunaan dan manfaat bersih pada sistem fingerprint berpengaruh terhadap kepuasan mahasiswa. 
Pada penelitian ini kualitas sistem (KS), kualitas informasi (KI), kualitas layanan (KL), penggunaan $(\mathrm{P})$ dan manfaat bersih $(\mathrm{MB})$ merupakan variabel eksogen sedangkan kepuasan mahasiswa (KM) merupakan variabel endogen. Berdasarkan tahapan SEM, diagram alur dibuat untuk menguji kesesuaian model dengan data penelitian. Model yang digunakan dalam penelitian ini berdasarkan teori DeLone \& McLean. Model diagram alur yang peneliti buat menggunakan bantuan IBM SPSS AMOS 24 pada disajikan pada gambar 1 .

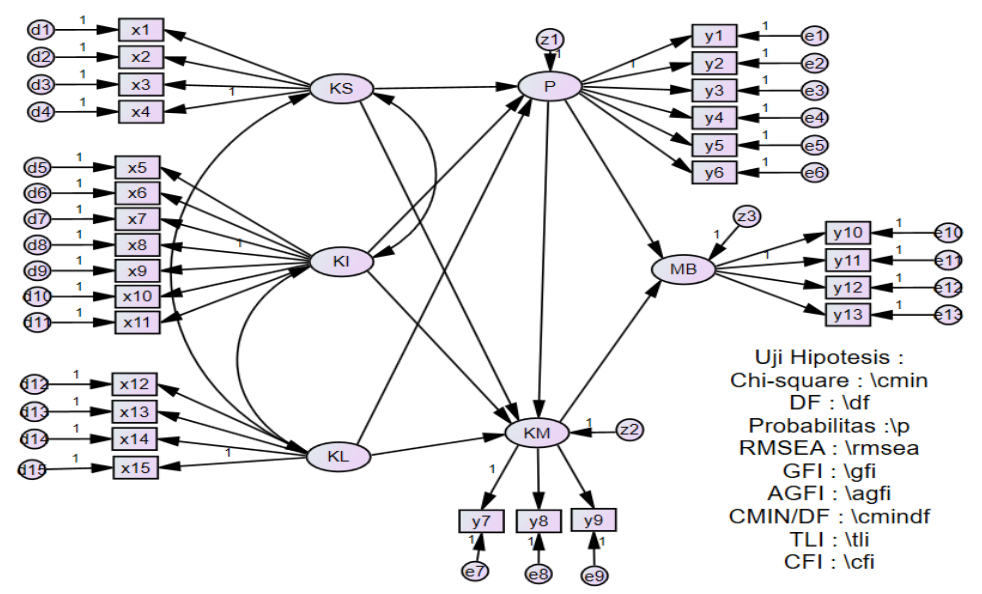

Gambar 1. Model Diagram Alir Hubungan antara Variabel Endogen dan Eksogen

\section{Persyaratan Model SEM}

Model diagram alir yang dibangun dalam penelitian ini dapat diyatakan fit apabila model telah mampu memenuhi persyaratan Goodness of Fit. Goodness of Fit merupakan tujuan utama dalam analisis SEM untuk menguji model layak atau tidak untuk digunakan dalam penelitian ini. Menurut Ferdinand ada 7 indeks penilaian untuk menguji model penelitian yaitu :

a. Chi-square, model dikatakan baik apabila memiliki nilai chi-square yang kecil

b. RMSEA (the Root Mean Square Error of Approximation), nilai RMSEA yang diharapkan adalah lebih kecil atau sama dengan 0,08 untuk menunjukkan bahwa model telah fit.

c. GFI (Goodness of Fit Index), merupakan ukuran statistik yang memiliki nilai rentang antara 0 hingga 1 . Semakin tinggi nilainya menandakan model semakin fit.

d. AGFI (Adjusted Goodness of Fit Index), nilai yang direkomendasikan adalah lebih tinggi atau sama dengan 0,90 .

e. CMIN/DF adalah hasil bagi antara chi-square dengan degree of freedom apabila nilai indeks kurang dari 2 maka model dapat dikatakan fit.

f. TLI (Tucker-Lewis Index), merupakan indeks tambahan yang membandingkan sebuah model yang diuji terhadap model dasar. Nilai ideal dari TLI adalah 0,90. 
g. CFI (Comparative Fit Index), apabila nilai indeks mendekati satu menandakan model semakin fit. Nilai yang direkomendasikan adalah lebih dari 0,90.

\section{HASIL DAN PEMBAHASAN}

Data yang didapatkan pada penelitian ini berupa data angket kuisioner dengan 5 pilihan jawaban. Jumlah pertanyaan angket sebanyak 30 pertanyaan tertutup. Validasi kuesioner penelitian ini dilakukan oleh dua orang pakar bahasa sebagai validator. Hasil validasi kuesioner menunjukkan bahwa kuesioner valid dan siap untuk diujicobakan. Uji reliabilitas menggunakan rumus Cronbach Alpha dengan nilai ideal koefisien reliabilitas adalah di atas 0,7. Uji reliabilitas kuisioner dilakukan kepada 30 orang responden dan mendapatkan nilai Cronbach Alpha sebesar 0,942 lebih besar dari 0,70 sehingga kuesioner dinyatakan reliabel sebagai instrumen pengumpulan data.

Uji prasyarat asumsi SEM meliputi uji normalitas dan uji outlier. Uji normalitas pada penelitian ini menggunakan uji normalitas skewness dan kurtois. Data akan terdistribusi normal apabila nilai c.r (critical ratio) multivariate berada pada interval $-2,58<$ c.r $>2,58$ (Limantoro et al., 2013). Hasil pengujian dengan bantuan IBM SPSS AMOS 24 menunjukkan bahwa tidak ada variabel yang berada di luar interval 2,58< c.r $>2,58$ sehingga disimpulkan data berdistribusi normal. Metode estimasi SEM yang digunakan adalah model Maximum Likelihood. Uji outlier adalah pengujian untuk menemukan data yang menyimpang dari sekumpulan data lainnya. Untuk menguji data outlier menggunakan jarak mahalanobis. Nilai batas jarak mahalanobis dalam penelitian ini dengan derajat bebas 28 dan tingkat signifikansi $\alpha<0,001$ adalah 56,892. Data yang memiliki jarak mahalanobis lebih dari 56,892 adalah data outlier. Hasil output penghitungan mahalanobis pada program AMOS menunjukkan tidak ada data yang melebihi batasan mahalanobis sehingga tidak terdapat data outlier.

\section{Model Diagram Alur}

Tujuan dalam penelitian ini adalah untuk menentukan faktor-faktor yang mempengaruhi sistem fingerprint scanner dan mengetahui besar indeks kepuasan mahasiswa terhadap sistem fingerprint scanner Masjid Jami' UNIDA Gontor dengan mengujinya menggunakan model DeLone \& McLean sehingga matriks yang digunakan adalah matriks korelasi. AMOS sudah melakukannya secara otomatis dengan mengubah dari data mentah ke bentuk korelasi maka peneliti tidak perlu untuk membuatnya. Menurut Ghozali ukuran sampel untuk analisis SEM yang menggunakan model estimasi Maximum Likelihood Estimation (MLE) adalah 100-200 dikarenakan sampel pada penelitian ini berjumlah 120 mahasiswa 
maka estimasi model menggunakan MLE. Setelah model data diinput maka akan muncul hasil estimasi disajikan pada Gambar 2.

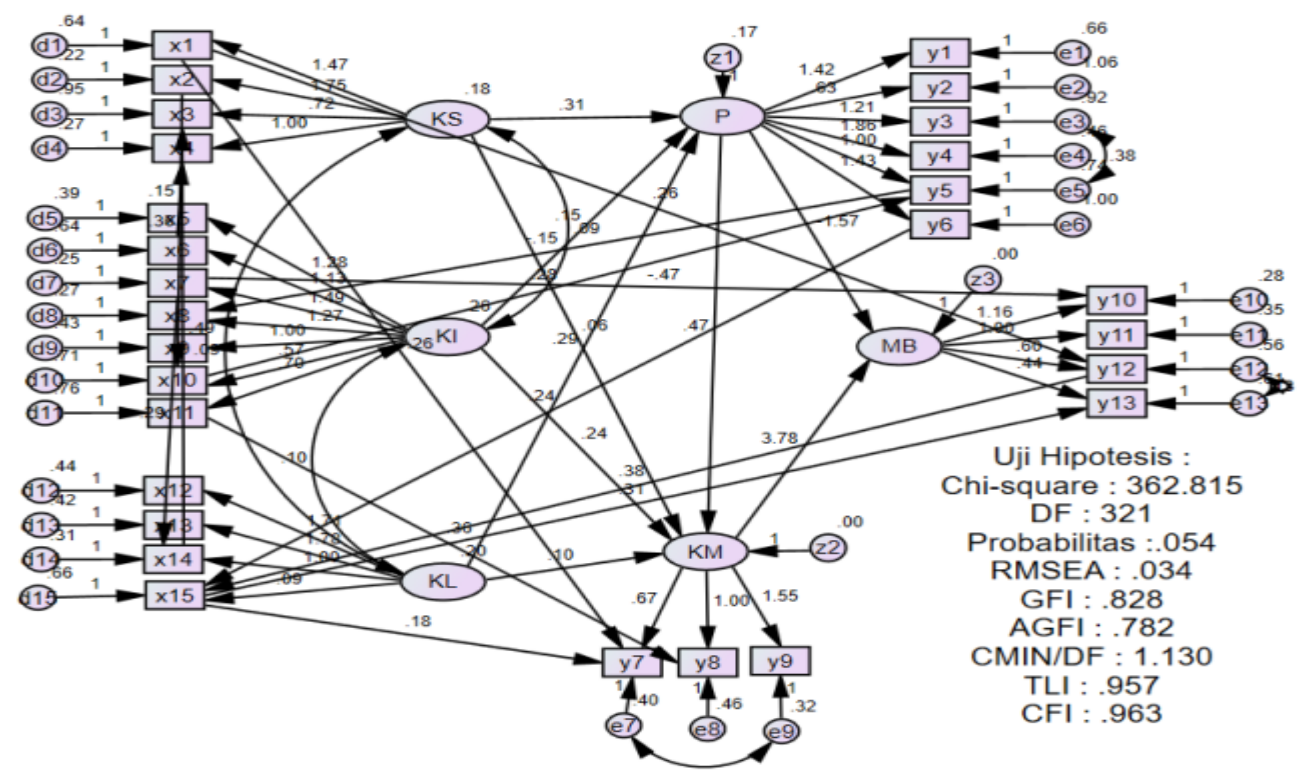

Gambar 2. Model Diagram Alur atau Full dan Hybrid Model

\section{Identifikasi Model}

Berdasarkan hasil output analisis data diperoleh bahwa model diagram alur dalam penelitian ini adalah over indentified. Hasil Degree of Freedom (DF) diperoleh dari total jumlah data kovarians yang berjumlah 406 dikurangi jumlah parameter yang berbeda yang sudah diestimasi berjumlah 68 maka akan ditemui hasil sebesar 338. Hal ini membuat model bernilai over identified. Hal ini terjadi karena hasil DF adalah lebih dari 0, sehingga menghasilkan DF positif dan membuat model dapat diterima.

\section{Evaluasi Model Kriteria Goodness of Fit}

Tujuan utama dalam metode SEM adalah mengetahui nilai dari Goodness of Fit (GOF) suatu model. Karena cocok atau tidaknya suatu model untuk analisis SEM dapat dilihat dari nilai Goodness of Fit. Hasil Goodness of Fit disajikan pada Tabel 1.

Tabel 1. Hasil Goodness of Fit

\begin{tabular}{cccc}
\hline Goodness of Fit Index & Cut of Point & Hasil Analisis & Kesimpulan \\
\hline Chi-Square & $<394,626$ & 362,815 & Fit \\
DF & $>0$ & 321 & Fit \\
Probabilitas & $\geq 0,05$ & 0,054 & Fit \\
RMSEA & $\leq 0,08$ & 0,034 & Fit \\
GFI & $\geq 0,90$ & 0,828 & Marginal Fit \\
AGFI & $\geq 0,90$ & 0,782 & Marginal Fit \\
CMIN/DF & $\leq 2,00$ & 1,130 & Fit \\
TLI & $\geq 0,90$ & 0,957 & Fit \\
CFI & $\geq 0,90$ & 0,963 & Fit \\
\hline
\end{tabular}


Pada Tabel 1 dapat diketahui Chi-square yang dihasilkan bernilai 362,815 lebih kecil dari chi-square table yaitu 394,626 dengan DF bernilai 321 dan nilai probabilitas sebesar 0,054. Hal ini menunjukkan bahwa model memiliki kecocokan yang baik. Hasil ini didukung dengan ukuran GOF lain yang menunjukkan kecocokan yang baik (fit) maka dapat disimpulkan bahwa model layak digunakan dalam penelitian ini.

\section{Reliabilitas Model}

Setelah model dinyatakan fit langkah terakhir dalam analisis SEM adalah menguji reliabilitas model. Reliabilitas adalah indeks yang menunjukkan sejauh mana suatu alat pengukur dapat dipercaya atau diandalkan. Uji reliabilitas berfungsi untuk menentukan kekonsistensian pengukur indikator - indikator dari variabel laten. Analisis reliabilitas model pengukuran dilakukan dengan menghitung nilai construct reliability (CR) dan variance extracted. Nilai ideal dari construct reliability adalah 0,70 sedangkan nilai ideal dari variance extracted adalah 0,50.(Aritonang et al., 2017) Hasil perhitungan construct reliability dan variance extracted disajikan pada Tabel 2.

Tabel 2 Hasil perhitungan construct reliability dan variance extracted

\begin{tabular}{ccccc}
\hline Variabel & Construct Reliability & Variance Extracted & Indeks & Kesimpulan \\
\hline Sistem & 0,921 & 0,764 & $76,4 \%$ & Valid \& Reliabel \\
Informasi & 0,941 & 0,712 & $71,2 \%$ & Valid \& Reliabel \\
Layanan & 0,919 & 0,795 & $79,5 \%$ & Valid \& Reliabel \\
Penggunan & 0,921 & 0,682 & $68,2 \%$ & Valid \& Reliabel \\
Kepuasan & 0,852 & 0,765 & $76,5 \%$ & Valid \& Reliabel \\
Mahasiswa & & & & \\
Manfaat Bersih & 0,816 & 0,616 & $61,6 \%$ & Valid \& Reliabel \\
\hline
\end{tabular}

Pada Tabel 2 dapat diketahui bahwa hasil semua variabel mendapatkan nilai construct reliability di atas 0,70 sehingga dapat disimpulkan bahwa setiap variabel telah reliabel. Dari penghitungan variance extracted diperoleh indeks kepuasan mahasiswa sebesar 76,5\% hasil ini lebih besar dari nilai minimal sebesar $50 \%(0,5)$. Hasil ini menjelaskan bahwa di tahun perdana sistem fingerprint scanner sudah memberikan kepuasan bagi mahasiswa UNIDA Gontor. Kualitas layanan merupakan variabel dengan indeks terbesar sebesar 79,5 \%. Hal ini menandakan bahwa pengelola sukses memaksimalkan layanan yang terdapat pada sistem fingerprint. Manfaat bersih merupakan variabel dengan indeks terkecil pada penelitian ini sebesar $61,6 \%$ dibanding kualitas sistem, kualitas informasi atau penggunaan yang masingmasing mendapatkan indeks sebesar 76,4\%, 71,2\%, dan 68,2\%. Berdasarkan hasil analisis yang dilakukan dalam penelitian ini, dapat disimpulkan bahwa kualitas sistem, kualitas informasi, kualitas layanan, penggunaan dan manfaat bersih memberikan pengaruh terhadap kepuasan pengguna. Hal ini sesuai dengan hasil penelitian Septianita et al, yang menyatakan 
bahwa kualitas sistem, kualitas informasi, dan kualitaas pelayanan memberikan pengaruh positif terhadap kepuasaan pengguna (Septianita et al., 2014).

\section{SIMPULAN}

Dalam penelitian ini diperoleh faktor-faktor yang mempengaruhi kepuasan mahasiswa terhadap fingerprint scanner yaitu kualitas sistem, kualitas informasi, kualitas layanan, penggunaan dan manfaat bersih. Indeks kepuasan mahasiswa sebesar 76,5\% menjelaskan bahwa di tahun perdana sistem fingerprint scanner sudah memberikan kepuasan yang besar bagi mahasiswa UNIDA Gontor. Variabel yang paling mempengaruhi kepuasan mahasiswa adalah variabel kualitas layanan sebesar 79,5\%. Manfaat bersih merupakan variabel dengan indeks terkecil pada penelitian ini sebesar $61,6 \%$ dibanding kualitas sistem, kualitas informasi atau penggunaan yang masing-masing mendapatkan indeks sebesar 76,4\%, 71,2\%, dan $68,2 \%$.

\section{DAFTAR PUSTAKA}

Aritonang, P. L. E., Bayu, E. C., K, S. D., \& Prasetyo, J. (2017). Rancang Bangun Alat Pemilah Sampah Cerdas Otomatis. Snitt, 375-381. https://doi.org/10.1016/j.contraception.2014.02.009

DeLone, W. H., \& McLean, E. R. (2003). The DeLone and McLean model of information systems success: A ten-year update. Journal of Management Information Systems, 19(4), 9-30. https://doi.org/10.1080/07421222.2003.11045748

DeLone, W. H., \& McLean, E. R. (2016). Information Systems Success Measurement. In Foundations and Trends ${ }^{\circledR i n}$ Information Systems (Vol. 2, Issue 1, pp. 1-116). https://doi.org/10.1561/2900000005

Ferdinand, A. (2006). Simulated Equation Model dalam Penelitian Manajemen. BP UNDIP.

Indriani, M., \& Adryan, R. (2009). Kualitas Sistem Informasi dan Kepuasan Pengguna Sistem Informasi Perguruan Tinggi Universitas Syiah Kuala. Jurnal Telaah \& Riset Akuntansi, 2(1), 79-92.

Ismawati, D., \& Mazia, L. (2016). Efektivitas Penerapan Sistem Kehadiran Guru Dengan Menggunakan Fingerprint Terhadap Tingkat Kedisiplinan. Bina Insani ICT Journal, $3(2), 350-359$.

Kristin, L. S., Suputra, I. N., \& Sarbini. (2016). Pengaruh Penerapan Presensi Sidik Jari ( Fingerprint ) terhadap Kinerja Guru Melalui Motivasi Kerja di SMA Negeri 5 Malang. 
Jurnal Pendidikan Bisnis Dan Manajemen, 2(3), 170-177. https://doi.org/10.30871/jaic.v3i1.1051

Limantoro, S. E., Surjani, R. M., \& Hidayat, M. A. (2013). Perbaikan Kualitas Layanan Untuk Meningkatkan Kepuasan Dan Loyalitas Konsumen Dengan Metode Servqual Dan Structural Equation Modeling (Sem) Di Mirota, Surabaya. Calyptra: Jurnal Ilmiah Mahasiswa Universitas Surabaya, 5(1), 1-12.

Ngantung, K. A., Najoan, M. E. I., Sugiarso, B. A., \& Paturusi, S. D. E. (2014). Desain dan Implementasi Sistem Absensi Fingerprint di Jaringan Kampus dan Terintegrasi Dengan Sistem Informasi Terpadu UNSRAT. E-Journal Teknik Elektro Dan Komputer, 3(1), 8186.

Saputro, P. H., Budiyanto, D., \& Santoso, J. (2016). Model Delone and Mclean Untuk Mengukur Kesuksesan E-Government Kota Pekalongan. Scientific Journal of Informatics, 2(1), 1-8. https://doi.org/10.15294/sji.v2i1.4523

Sasongko, E. N., Mustafid, \& Rusgiyono, A. (2016). Penerapan Metode Structural Equation Modeling Untuk Analisis Kepuasan Pengguna Sistem Informasi Akademik Terhadap Kualitas Website (Studi Kasus pada Website sia.undip.ac.id). Jurnal Gaussian, 5(3), $395-404$.

Septianita, W., Winarno, W. A., \& Arif, A. (2014). Pengaruh Kualitas Sistem, Kualitas Informasi, Kualitas Pelayanan Rail Ticketing System (RTS) Terhadap Kepuasan Pengguna (Studi Empiris Pada PT. KERETA API INDONESIA (PERSERO) DAOP 9 JEMBER). E-Journal Ekonomi Bisnis Dan Akuntansi, 1(1), 53-56. https://doi.org/10.19184/ejeba.v1i1.570 